\title{
Giant juvenile fibroadenoma of the breast: a clinical case
}

\author{
Suleyman U. Celik, M.D. ${ }^{a}$, Dilara Besli Celik, M.D. ${ }^{b}$, Ece Yetiskin, M.D. ${ }^{a}$, Ergun Ergun, M.D., \\ Sibel Percinel, M.D. ${ }^{d}$ S Seher Demirer, M.D. ${ }^{a}$
}

\begin{abstract}
Juvenile giant fibroadenoma is a benign breast tumor and rare variant of the fibroadenomas. Clinical presentation is usually a painless, solitary and unilateral breast mass. It accounts for $0.5 \%-2 \%$ of all fibroadenomas and exact etiology is not known; however, hormonal influences are thought to be contributing factors.

We present a case of a $20 \mathrm{~cm}$ diameter giant juvenile fibroadenoma of the breast in a 14-year-old girl. The patient was suffering from a painless, progressively enlarging mass for 1 year. Ultrasound revealed fibroadenoma and total surgical excision was performed. The patient is doing well in ten months of follow up.
\end{abstract}

Key words: breast neoplasms, juvenile giant fibroadenoma, surgery.

http: / / dx.doi.org/10.5546/ aap.2017.eng.e428

To cite: Celik SU, Besli Celik D, Yetiskin E, et al. Giant juvenile fibroadenoma of the breast: a clinical case. Arch Argent Pediatr 2017;115(6):e428-e431.

\section{INTRODUCTION}

Fibroadenoma is a common tumor of the female breast which contains both connective tissue and epithelial proliferation without atypia. Usually arises before 30 years of age and grows slow. ${ }^{1}$ Fibroadenomas appear more often in the left breast than the right and in the upper outer quadrant than in the lower. ${ }^{2}$

a. Department of Surgery Ankara University School of Medicine, Ankara, Turkey.

b. Department of Pediatrics, Gazi University School of Medicine, Ankara, Turkey.

c. Department of Pediatric Surgery, Ankara University School of Medicine, Ankara, Turkey.

d. Department of Pathology, Ankara University School of Medicine, Ankara, Turkey.

E-mail address:

Ergun Ergun, M.D.: drergunergun@gmail.com

Funding: None.

Conflict of interest: None.

Received: 1-25-2017

Accepted: 5-8-2017
Fibroadenoma is a benign breast tumor and usually it is solid, mobile, painless, unilateral, and well-circumscribed. ${ }^{1,2}$ It arises from epithelium and stroma of the terminal duct-lobular unit. ${ }^{3}$ If the fibroadenoma is encountered in adolescent age, it shows rapid growth and becomes more than $5 \mathrm{~cm}$ in diameter or more than 500 grams or replaces at least $80 \%$ of the breast, is called "giant juvenile fibroadenoma" (GJF)., ${ }^{1,3}$ GJFs can double in size within few months and can reach up to $20 \mathrm{~cm}$ in diameter. Skin ulceration and prominent superficial veins can develop due to rapid growth in GJF. ${ }^{3,4}$ The etiology is not clear yet but is considered that increased estrogen levels and estrogen receptor sensitivity can cause these enormous growth and changes. ${ }^{3,5}$

The diagnosis of GJF can be confirmed with ultrasonographic examination and tissue biopsy. ${ }^{1,3,4}$ Aspiration cytology demonstrates sheets of hyperplastic, benign, ductal epithelial cells with myoepithelial cells and a background of benign bipolar nuclei and blood, without inflammatory fat cells. ${ }^{3,4}$ The target of treatment is complete excision of lesion with preserving lactation function and cosmesis. ${ }^{4-6}$ We report a patient with GJF of left breast, the surgical approach and outcome.

\section{Case report}

A 14-year-old girl without any previous medical history, presented with a one-year history of painless, palpable, and progressively enlarging mass in the left breast. There was no history of trauma, fever, anorexia or weight loss. Breast examination revealed a $20 \times 15 \mathrm{~cm}$ well-circumscribed and mobile mass in the left breast with nipple retraction, while the other breast was normal (Figure 1). The mass was firm, round, and not fixed to the underlying structure. The skin was tense with scattered redness and prominent superficial veins. No palpable axillary lymphadenopathy was detected and there were no positive findings in the laboratory examination. Family history was also negative. On physical examination, her weight was $46 \mathrm{~kg}$ (10th-25th percentile), height was $163 \mathrm{~cm}$ (75th-90th percentile) and body mass index was $17.3 \mathrm{~kg} / \mathrm{m}^{2}$. She reached menarche at 
13 years.Blood count, biochemical tests, estrogen, progesterone and other hormone levels were in normal limits according to the menstrual period phase (follicular) (Table 1). Ultrasonography demonstrated a well-circumscribed, homogeneous, and isoechoic $20 \times 16 \times 8 \mathrm{~cm}$ mass occupying nearly the entire breast. Pathological evaluation of the core biopsy specimen revealed fibroadenoma. Total excision of the mass preserving the normal breast tissue, skin, and nipple-areola complex was performed under general anesthesia (Figure 2). Macroscopically, a circumscribed and encapsulated lesion of
658 grams and $17 \times 13 \times 5.5 \mathrm{~cm}$ in size with a cut surface of grey-white in color and solid in consistency was detected. Microscopically, a well limited and encapsulated lesion of both epithelial and stromal components was observed. Variable sized ducts with a pericanalicular pattern lined by bilayered epithelium without cytological atypia were seen in a fibrous stroma. Apical snouts and gynecomastia-like micropapillary projections were observed in the luminal epithelial layer. Around ducts, a stroma showing myxoid changes was seen in a circumferential fashion. Stromal atypia or mitoses were not detected (Figure 3). On

TABLE 1. Laboratory results

\begin{tabular}{|c|c|c|}
\hline Laboratory test & Patient's value & Normal value \\
\hline Hemoglobin & $14 \mathrm{~g} / \mathrm{dL}$ & $11,5-15 \mathrm{~g} / \mathrm{dL}$ \\
\hline White blood cell & $4,69 \times 10^{9} / \mathrm{L}$ & $4,5-13 \times 10^{9} / \mathrm{L}$ \\
\hline Platelets & $217 \times 10^{9} / \mathrm{L}$ & $150-400 \times 10^{9} / \mathrm{L}$ \\
\hline C- reactive protein & $0,1 \mathrm{mg} / \mathrm{L}$ & $0-5,0 \mathrm{mg} / \mathrm{L}$ \\
\hline Blood urea nitrogen & $8 \mathrm{mg} / \mathrm{dL}$ & $5-18 \mathrm{mg} / \mathrm{dL}$ \\
\hline Creatinine & $0,62 \mathrm{mg} / \mathrm{dL}$ & $0,57-0,87 \mathrm{mg} / \mathrm{dL}$ \\
\hline Sodium & $142 \mathrm{mEq} / \mathrm{L}$ & $136-145 \mathrm{mEq} / \mathrm{L}$ \\
\hline Albumin & $4,7 \mathrm{~g} / \mathrm{dL}$ & $3,2-4,8 \mathrm{~g} / \mathrm{dL}$ \\
\hline Lactate dehydrogenase & $184 \mathrm{U} / \mathrm{L}$ & $120-246 \mathrm{U} / \mathrm{L}$ \\
\hline International normalized ratio & 1,02 & $0,84-1,11$ \\
\hline Carcinoembryogenic antigene & $<0,5 \mathrm{ng} / \mathrm{mL}$ & $0-2,5 \mathrm{ng} / \mathrm{mL}$ \\
\hline Cancer antigene 15-3 & $16,4 \mathrm{U} / \mathrm{mL}$ & $0-32,4 \mathrm{U} / \mathrm{mL}$ \\
\hline Cancer antigene 19-9 & $7,51 \mathrm{U} / \mathrm{mL}$ & $0-30,9 \mathrm{U} / \mathrm{mL}$ \\
\hline Cancer antigene $72-4$ & $<0,2 \mathrm{U} / \mathrm{mL}$ & $0-6,9 \mathrm{U} / \mathrm{mL}$ \\
\hline Cancer antigene 125 & $9,3 \mathrm{U} / \mathrm{mL}$ & $0-30,2 \mathrm{U} / \mathrm{mL}$ \\
\hline Alfa feto protein & $1,3 \mathrm{ng} / \mathrm{mL}$ & $0-8 \mathrm{ng} / \mathrm{mL}$ \\
\hline Luteinizing hormone & $2,64 \mathrm{IU} / \mathrm{L}^{*}$ & $1,9-12,5 \mathrm{IU} / \mathrm{L}^{*}$ \\
\hline Estradiol & $51,98 \mathrm{pg} / \mathrm{mL}^{*}$ & $19,5-144,2 \mathrm{pg} / \mathrm{mL}^{*}$ \\
\hline Follicule stimulating hormone & $6,65 \mathrm{IU} / \mathrm{L}^{*}$ & $2,5-10,2 \mathrm{IU} / \mathrm{L}^{*}$ \\
\hline Prolactin & $12,14 \mathrm{ng} / \mathrm{mL}^{* *}$ & $2,8-29,2 \mathrm{ng} / \mathrm{mL}^{* *}$ \\
\hline Progesterone & $0,9 \mathrm{ng} / \mathrm{mL}^{*}$ & $0,15-1,4 \mathrm{ng} / \mathrm{mL}^{*}$ \\
\hline Total testosterone & $40 \mathrm{ng} / \mathrm{dL}$ & $14-76 \mathrm{ng} / \mathrm{dL}$ \\
\hline
\end{tabular}

${ }^{*}$ Normal value for phollicular phase of menstrual period.

${ }^{* *}$ Normal value for non-pregnancy period.

Figure 2. Macroscopic view of the excised giant fibroadenoma specimen

Figure 1. Preoperative view

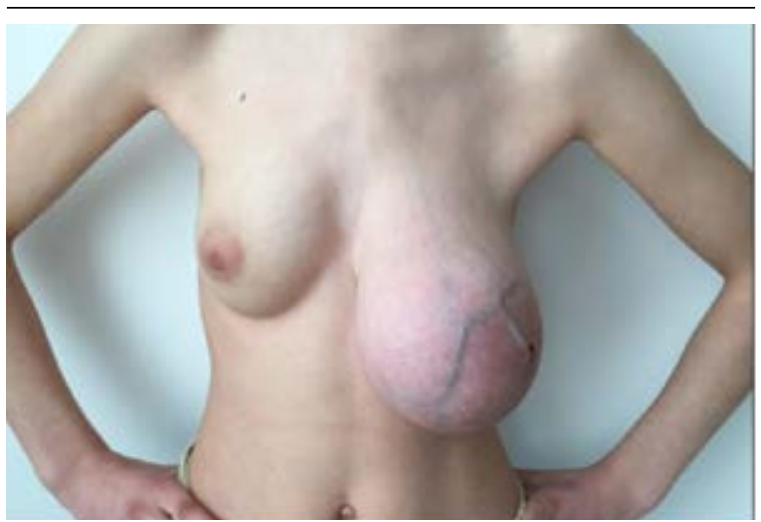

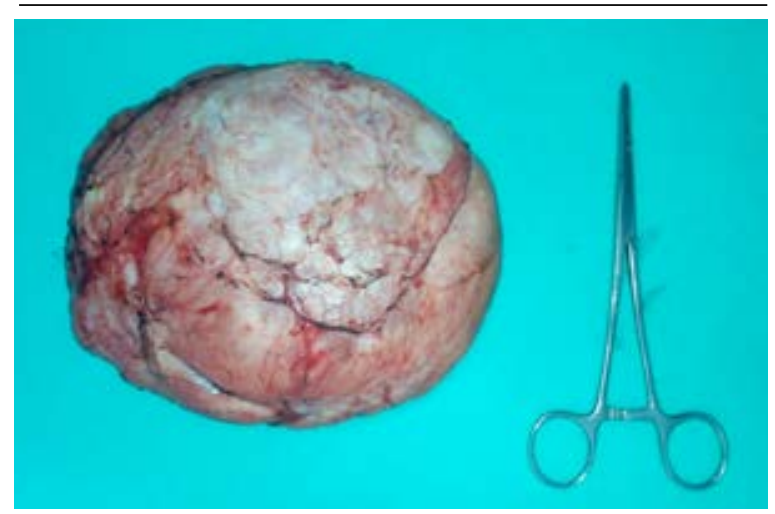

The mass is well circumscribed and encapsulated with $658 \mathrm{~g}$ and $17 \times 13 \times 5.5 \mathrm{~cm}$ in size. 
the basis of the weight, size and morphological findings of the lesion and the age of the patient, the lesion was diagnosed as GJF. No complication was encountered and the patient was discharged four days after the operation. The patient is now in regular follow-up for ten months and doing well (Figure 4).

\section{DISCUSSION}

In the treatment of typical fibroadenomas, conservative approach is usually favored in small fibroadenomas because they are not a known risk factor for breast cancer, and about $10 \%$ to $40 \%$ of cases resolve spontaneously. ${ }^{5}$ Sosin et al. ${ }^{1}$ reported in a large study of 153 cases that mean age is 16.7 years old and mean size of lesion is $11.2 \mathrm{~cm}$ in diameter. In that case,the patient was 14 years old and the size of lesion was $17 \mathrm{~cm}$.

Juvenile fibroadenoma can grow rapidly and occupy most of breast. ${ }^{6}$ Rapid growth may lead to compression in the surrounding tissue, deterioration in breast structure,nipple retraction, and expansion of superficial veins. ${ }^{3,5-8}$ Because of rapid growth, GJF may be evaluated as a malignancy whereas malignant transformation is rare and less than $0.3 \% .^{5}$

FIGURE 3. Hystopathology

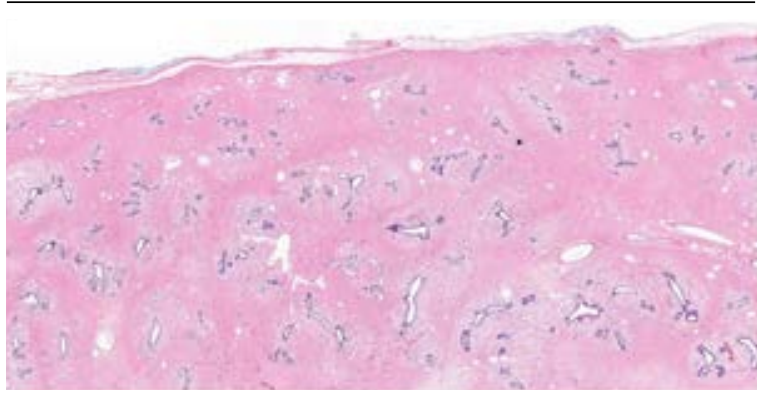

Well circumscribed and encapsulated lesion with epithelial and stromal components (x1.6, hematoxylin and eosin).

FIGURE 4. Postoperative view at the 10th month

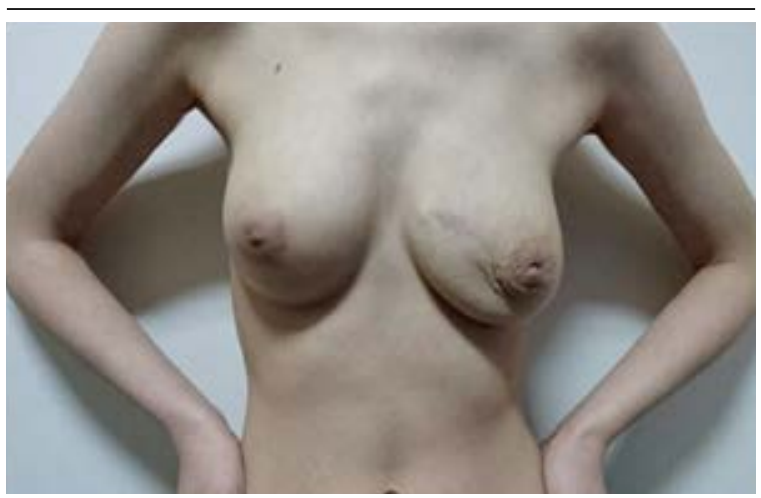

GJF should especially be distinguished from phyllodes tumor which is an uncommon fibroepithelial tumor of the breast which is more likely to occur in women over 35 years. ${ }^{3-5,8}$ Phyllodes tumors may be separated from GJF with their increased mitotic activity in histological examination. They can be rarely malignant and the surgical choice should be excision with preservation of breast. ${ }^{1,6,7}$ Besides phyllodes tumor, juvenile breast hypertrophy, giant lipoma, hamartoma of breast, inflammatory processes, huge cysts, and adenocarsinoma should be kept in mind in differential diagnosis. 3,6,7,9,10

Giant fibroadenomas may be classified as juvenile and adult in terms of age and simple and complex of histological appearance. ${ }^{10}$ About $90 \%$ of the tumors are low grade or benign and so, juvenile fibroadenomas should be treated by lumpectomy with conservation of normal breast tissue; small lesions can be treated by simple enucleation from an areolar incision. ${ }^{4,6,7}$ Complex fibroadenomas have higher malignancy risk. ${ }^{10}$ Although rare, subcutaneous mastectomy can be performed for giant fibroadenomas if required and after mastectomy, patients mostly undergo reconstructive surgery. ${ }^{11}$ The size of tumor, age of the patient and the stage of sexual maturity should be considered to perform appropriate surgical approach. However, the recurrence rate is about $33 \%$ at the 5 -year follow-up after excision., ${ }^{5,9}$ Chang et al. ${ }^{6}$ advocated for reconstruction according to three basic principles: "preserving all the normal breast parenchyma, adjusting the skin envelope, and positioning the nipple-areola complex for symmetry with the opposite breast". In our case, surgical excision of left breast lump with preserving of normal breast tissue, skin and nipple-areola complex was carried out.

\section{REFERENCES}

1. Sosin M, Pulcrano M, Feldman ED, et al. Giant juvenile fibroadenoma: a systematic review with diagnostic and treatment recommendations. Gland Surg 2015;4(4):312-21.

2. Vijaykumar A, Ajitha MB, Shivaswamy BS, et al. A systematic study on fibroadenoma of the breast. Eur J Surg Sci 2012;3(3):80-5.

3. Goyal S, Garg G, Narang S. Giant fibroadenoma of the breast in a pre-pubertal girl: a case report. Int J Cancer Ther Oncol 2014;2(1):020113.

4. Ng WK, Mrad MA, Brown MH. Juvenile fibroadenoma of the breast: Treatment and literature review. Can J Plast Surg 2011;19(3):105-7.

5. Song BS, Kim EK, Seol H, et al. Giant juvenile fibroadenoma of the breast: a case report and brief literature review. Ann Pediatr Endocrinol Metab 2014;19(1):45-8.

6. Chang DS, McGrath MH. Management of benign tumors of the adolescent breast. Plast Reconstr Surg 2007;120(1):e13-9. 
7. Yagnik VD. Juvenile giant fibroadenoma. Clin Pract 2011;1(3):e49.

8. Çelik MF, Dural AC, Ünsal MG, et al. Giant juvenile fibroadenoma. Ulus Cerrahi Derg 2014;31(2):96-8.

9. Matz D, Kerivan L, Reintgen M, et al. Breast preservation in women with giant juvenile fibroadenoma. Clin Breast Cancer 2013;13(3):219-22.
10. Gkali C, Giannos A, Primetis E, et al. Giant Juvenile Fibroadenoma in a 12-Year-Old Girl: Ultrasonography, Elastography, Clinical, and Pathology Findings of This Rare Type of Fibroadenoma. Ultrasound Q 2017;33(1):51-4.

11. Laitano FF, Neto FL, Zerwes FP. Bilateral giant juvenile fibroadenomas of the breasts-a rare indication for bilateral skin reducing mastectomy. Gland Surg 2016;5(4):435-8. 